\title{
Inicjatywy klastrowe jako szansa rozwoju przemysłu meblarskiegow Polsce w warunkach kryzysu - przykład Swarzędzkiego Klastra Producentów Mebli
}

\author{
Cluster initiatives as a chance for the development \\ of the furniture industry in Poland in the conditions \\ of a crisis: The example of the Swarzędz Cluster \\ of Furniture Producers
}

\begin{abstract}
Streszczenie: Głównym celem artykułu jest przedstawienie inicjatyw klastrowych jako szansy na rozwój małych i średnich przedsiębiorstw przemysłu meblarskiego w Polsce (w szczególności w warunkach kryzysu). Jest to ważna gałąź krajowej gospodarki, generująca ok. 2\% PKB i ok. 6\% polskiego eksportu. Na początku scharakteryzowano stan polskiego przemysłu meblarskiego w 2013 roku. Uwarunkowania i perspektywy rozwoju tej branży zostały przeanalizowane przy użyciu koncepcji pięciu sił Portera. Następnie przedstawiono ideę inicjatyw klastrowych jako formy współpracy pomiędzy konkurującymi ze sobą przedsiębiorstwami tej samej branży oraz przykłady inicjatyw klastrowych przemysłu meblarskiego w Polsce. W kolejnej części opisany został przypadek Swarzędza - miasta stolarzy i meblarzy o długich tradycjach rzemieślniczych, w którym wciąż funkcjonuje wiele małych i średnich przedsiębiorstw meblarskich. Zaprezentowano również Swarzędzki Klaster Producentów Mebli - inicjatywę koordynowaną przez Cech Stolarzy Swarzędzkich oraz projekt strategii rozwoju tego klastra, realizowany m.in. przy dofinansowaniu pozyskanym ze środków Programu Operacyjnego Innowacyjna Gospodarka.
\end{abstract}

\begin{abstract}
The main aim of this article is to present cluster initiatives as a chance for the development of small and medium-sized enterprises operating in the furniture industry in Poland (especially under crisis conditions). It is an important branch of the national economy, generating ca. $2 \%$ of the GDP and accounting for ca. $6 \%$ of Polish exports. Firstly, the state of the Polish furniture industry in 2013 is presented. The conditions and prospects of its development are analyzed using Porter's five forces concept. In the next part, the idea of cluster initiatives as a form of co-operation between competing enterprises is described and illustrated with the use of some examples from Poland as a whole. The paper ends with a case study of Swarzędz - a city of carpenters and furniture producers. This industry has a long tradition in Swarzędz and is sustained to the present day. Currently, the Swarzędz Cluster of
\end{abstract}


Furniture Producers is being formed with the initiative from the local Guild of Swarzędz Carpenters. Additionally, its development strategy is being established and is to be funded from the Innovative Economy Operational Programme.

Słowa kluczowe: inicjatywy klastrowe; kryzys; Polska; przemysł meblarski; Swarzędz

Keywords: cluster initiatives; crisis; Poland; furniture industry; Swarzedz

\section{WSTĘP}

Przemysł meblarski ma w Polsce długą tradycję i od dziesiątków lat stanowi ważną gałąź gospodarki. Zmiany, które nastąpiły od 1990 roku, zapoczątkowały nowy okres działalności przedsiębiorstw tej branży: niektóre z nich zostały sprywatyzowane, inne musiały nauczyć się funkcjonować w nowych warunkach, pojawiło się również wiele nowych podmiotów. Znaczna część drobnych producentów przyzwyczajonych do swoich tradycyjnych wyrobów miała trudności w odnalezieniu się na konkurencyjnym rynku, szczególnie gdy wskutek globalizacji dużego znaczenia nabrała elastyczność produktowa i procesowa, czyli zdolność szybkiego dostosowywania się do zmieniających się preferencji klientów i zmian technologii. Jednym z rozwiązań ułatwiających adaptację do tych zmian okazała się idea inicjatyw klastrowych - sformalizowanych porozumień przedsiębiorstw zlokalizowanych w niewielkiej odległości od siebie, które współpracują ze sobą w celu osiągnięcia wspólnych korzyści ${ }^{1}$.

Artykuł prezentuje inicjatywy klastrowe przemysłu meblarskiego jako szansę na rozwój przedsiębiorstw tej branży (szczególnie w warunkach kryzysu). Analiza odnosi się do dwóch skal przestrzennych: kraju oraz ośrodka przemysłu meblarskiego o długich tradycjach Swarzędza (miasta w województwie wielkopolskim). Opiera się na dwóch rodzajach źródeł: (1) wtórnych, dotyczących przemysłu meblarskiego i inicjatyw klastrowych w Polsce oraz (2) pierwotnych, pozyskanych podczas czterech wywiadów w Cechu Stolarzy Swarzędzkich oraz w Urzędzie Miasta i Gminy Swarzędz. Celem tych wywiadów było zebranie informacji na temat sytuacji na rynku mebli w Polsce oraz możliwości finansowania i realizacji projektów w jednej z przykładowych inicjatyw klastrowych - Swarzędzkim Klastrze Producentów Mebli².

\section{Stan i Perspektywy rozWoju PRZEMysŁu MEBlarskiego w Polsce}

Przemysł meblarski jest - wraz z przemysłem płyt drewnopochodnych, stolarki budowlanej, tartacznym, opakowań i pozostałymi - częścią przemysłu drzewnego. Według danych GUS oraz materiałów Ogólnopolskiej Izby Gospodarczej Producentów Mebli (www.oigpm.

\footnotetext{
${ }^{1}$ Inicjatywy klastrowe można określić jako zinstytucjonalizowane formy współpracy podmiotów klastra, co zostało szerzej wyjaśnione w tekście niniejszego artykułu.

${ }^{2} \mathrm{Za}$ udzielone informacje autorzy pragną w szczególności podziękować pani Małgorzacie Błachowiak-Długosz, koordynatorce Swarzędzkiego Klastra Producentów Mebli z Cechu Stolarzy Swarzędzkich.
} 
org.pl i www.meble.org.pl, 2013), Polska należy do liderów eksportu oraz produkcji mebli na świecie (w rankingach zajmuje odpowiednio 4 i 10 miejsce). Meblarstwo generuje ok. $2 \%$ polskiego PKB i pozytywnie wyróżnia się na tle innych branż gospodarki. W wartości eksportu, która w 2012 roku wyniosła 27,7 mld zł (co stanowiło ok. 6\% całego polskiego eksportu), zajmuje 3 miejsce, za przemysłem motoryzacyjnym oraz produkcją maszyn i urządzeń elektrycznych. W przemyśle meblarskim w 2012 roku pracowało 127,7 tys. osób, co stanowiło blisko 7\% ogółu zatrudnionych w Polsce.

Na rynku mebli w Polsce zauważa się dużą konkurencję, ponieważ aktywnie działa na nim ok. 100 firm zaliczanych do grupy dużych przedsiębiorstw, ok. 400 przedsiębiorstw średnich i 1000 firm małych (o zatrudnieniu od 10 do 49 pracowników). Obrazu dopełnia bardzo liczna grupa ok. 5000 mikroprzedsiębiorstw oraz ok. 1000 podmiotów działających w obszarze handlu hurtowego i detalicznego mebli. Część dużych przedsiębiorstw należy do inwestorów zagranicznych, w których dominują inwestorzy niemieccy. Liczbę firm kooperujących z różnych branż powiązanych z produkcją mebli szacuje się na 20 tys.

Na Liście 500 „Polityki” - rankingu największych pod względem wielkości sprzedaży przedsiębiorstw w Polsce (Lista 500 Polityki, 2013) - wśród producentów i sprzedawców mebli najwyższe przychody w 2012 roku osiągnęły: Ikea Retail sp. z o.o. (1,9 mld zł), GK Pfleiderer Grajewo SA (1,7 mld zł), GK Black Red\&White SA z Biłgoraja (1,6 mld), Grupa Nowy Styl z Krosna (1 mld zł), Grupa Meblowa Szynaka z Lubawy (0,6 mld zł), Sun Garden Polska sp z o.o. s.k. z Malanowa (0,6 mld zł), GK Paged SA z Warszawy (0,6 mld zł), GK Forte SA z Ostrowi Mazowieckiej (0,5 mld zł). Przedsiębiorstwa te, oprócz mebli, mają najczęściej w swoim portfolio również inne wyroby drewniane: płyty meblowe, podłogi, sztuczne okleiny, a ich zakłady produkcyjne niekiedy są zlokalizowane też poza miastem będącym ich główną siedzibą. Inne duże przedsiębiorstwa z branży drzewnej na Liście 500 wytwarzają produkty z papieru i tektury, a także podłogi i płyty drewniane.

Przemysł meblarski w Polsce szczególnie szybko rozwijał się od 1998 do 2007 roku, gdy wskaźniki produkcji sprzedanej oraz rentowności netto rokrocznie systematycznie rosły. Dynamika produkcji sprzedanej wynosiła wtedy od kilku do kilkunastu procent rocznie. Głównymi stymulatorami wzrostu w sektorze meblarskim, a także w całej branży drzewnej, były m.in.: zwiększony napływ bezpośrednich inwestycji zagranicznych, korzystne dla eksporterów kursy walut, dobra koniunktura na rynkach zagranicznych, wzrost standardów dotyczących jakości polskich wyrobów, a później również perspektywa członkostwa i od 2004 roku członkostwo w Unii Europejskiej (por. Koszarek, 2005; Kalupa, 2007).

Kłopoty polskiego przemysłu meblarskiego, który był silnie uzależniony od eksportu, zaczęły się wraz z nadejściem ogólnoświatowego kryzysu finansowego. Osłabiony złoty oraz problemy gospodarcze na rynkach zachodnioeuropejskich spowodowały ograniczenie zagranicznego popytu na polskie meble, zwłaszcza na wyroby droższe. Szczególnie boleśnie branża odczuła ograniczenie zamówień przez kontrahentów z Niemiec, które były i są głównym odbiorcą polskich mebli. Z powodu dekoniunktury w budownictwie mieszkaniowym zmniejszył się także popyt na meble na rynku krajowym, napędzany głównie sprzedażą mebli na pierwsze wyposażenie mieszkań. Przewidywano, że kryzys odsieje najsłabszych producentów mebli, a na rynku pozostaną sprawnie zarządzane, innowacyjne przedsiębiorstwa, 
zdolne do szybkiego dostosowania się do nowych trendów w meblarstwie i elastycznej reakcji na potrzeby konsumentów (Okrzesik, 2009).

W istocie, w ostatnich latach zauważalny był w Polsce nieznaczny spadek produkcji i zatrudnienia w przemyśle meblarskim. Analitycy rynku meblowego przewidują jednak powolne wychodzenie branży z recesji. Według Strzeleckiego (2013) w stosunku do okresu styczeń-wrzesień 2012 roku w tym samym okresie roku 2013 zmniejszyła się produkcja ilościowa wszystkich rodzajów mebli, poza meblami do siedzenia przekształcalnymi w miejsca do spania (których produkcja wzrosła z 2006 tys. do 2160 tys. sztuk). Specjalizacją eksportową Polski cały czas są meble do sypialni i składane krzesła, których połowa sprzedawana w Europie pochodzi z naszego kraju. Klasa wyrobów „krzesła i meble do siedzenia” stanowi prawie połowę wartości produkcji sprzedanej branży meblarskiej w Polsce. Biorąc pod uwagę ilość eksportowanych mebli, mimo zanotowanego spadku, Polska jest ich drugim eksporterem na świecie (za Chinami). Natomiast dane na temat wartości eksportowanych mebli wskazują, że Polska zajmuje czwarte miejsce, po Niemczech, Włoszech i Chinach. Różnica pozycji rankingowych wynika w głównej mierze z faktu niższych cen polskich mebli, które jednak cieszą się bardzo dobrą opinią dotyczącą ich jakości wśród zagranicznych konsumentów. Sytuacja polskiego eksportu mebli, mimo kryzysu, wciąż jest relatywnie dobra, a wstępne wskaźniki dla 2013 roku pozwalają zakładać, że ostatecznie wartość eksportowanych mebli osiągnie w tym roku rekordową sumę $29 \mathrm{mld}$ zł.

Jedną z bardziej znanych metod analizy pozycji konkurencyjnej i perspektyw rozwoju branży jest model pięciu sił Portera. Konkurencyjność badana jest w pięciu wymiarach: rywalizacji konkurencyjnej na rynku, zagrożenia ze strony nowych wejść na rynek, zagrożenia ze strony substytutów, siły przetargowej dostawców i siły przetargowej nabywców (Porter, 1996; 2008). Analizę tych pięciu sił dla przemysłu meblarskiego przedstawiono na ryc. 1.

Szczególnej uwagi wymagają dwa czynniki rozwoju przemysłu meblarskiego w Polsce, które należy uznać za istotne: natężenie rywalizacji konkurencyjnej oraz siła przetargowa odbiorców. Konkurencję można rozpatrywać zarówno w wymiarze krajowym - jako rywalizację kilku tysięcy producentów w Polsce (od mikroprzedsiębiorstw po duże firmy), jak i w wymiarze międzynarodowym - jako rywalizację na rynkach zagranicznych. Polskie produkty są cenione ze względu na wysoką jakość i relatywnie niską cenę. Jednocześnie jednak wzrost eksportu polskich mebli i wynikający z niego wzrost sprzedaży mogą wynikać z ogólnego wzrostu popytu na meble na świecie.

Za zagrożenie dla krajowych przedsiębiorstw trzeba uznać np. szwedzki koncern IKEA, który oferuje proste i funkcjonalne meble, w dużej mierze składane samodzielnie przez konsumentów. Na fali ujednolicenia preferencji klientów wskutek globalizacji IKEA rokrocznie zwiększa swoje zyski ze sprzedaży - obecnie ma już ok. 350 sklepów w 43 krajach i zatrudnia (łącznie: w produkcji, dystrybucji i sprzedaży) 139 tys. pracowników. Co ciekawe, Polska jest największym dostarczycielem drewna dla koncernu - ok. 22\% tego surowca pochodzi z naszego kraju (IKEA Group Sustainability Report 2012, 2013). W Polsce eksport wyprodukowanych przez IKEA mebli w ostatnich latach rośnie, a sprzedaż na rynek krajowy powoli, ale systematycznie maleje. 


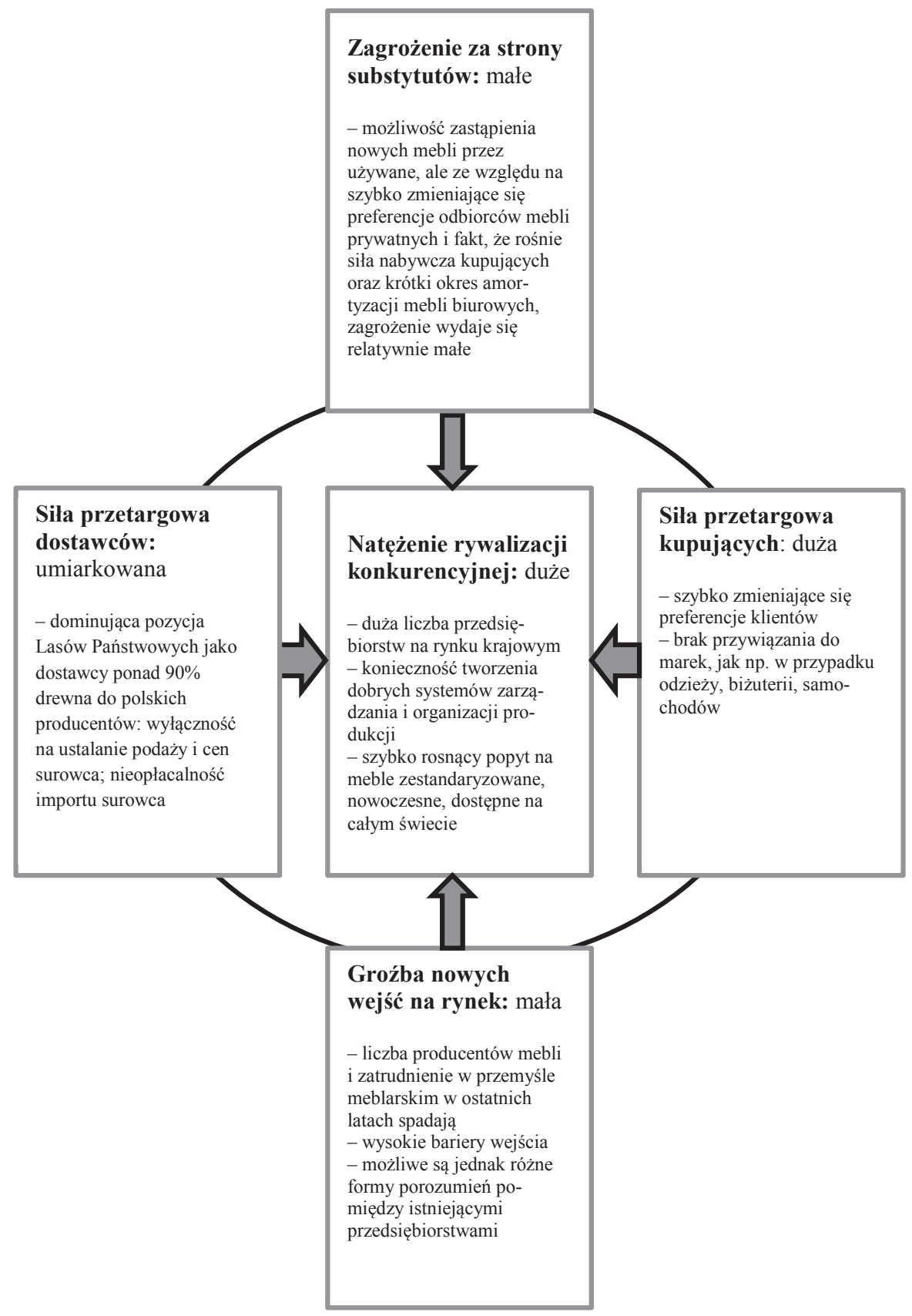

Ryc. 1. Uwarunkowania rozwoju przemysłu meblarskiego w Polsce w świetle koncepcji pięciu sił Portera

Źródło: opracowanie własne na podstawie materiałów Ogólnopolskiej Izby Producentów Mebli (2013) i wywiadów z wybranymi producentami mebli w Swarzędzu 
W odniesieniu do odbiorców produktów należy mieć na uwadze fakt, że preferencje klientów zmieniają się dzisiaj szybciej niż kiedyś. Przedsiębiorstwa powinny być elastyczne w zakresie designu, wzornictwa, kolorystyki i funkcjonalności oraz dostosowywać się do światowych trendów i nowoczesnych rozwiązań, popularnych wśród osób młodych. Jak twierdzą analitycy rynku meblowego, największy popyt będzie w najbliższych latach na meble do tzw. pierwszego wyposażenia mieszkań, a także na nowoczesne wyposażenia biurowe (por. Koszarek, 2005).

\section{INICJATYWY KLASTROWE JAKO SZANSA DLA PRZEMYSŁU MEBLARSKIEGO} W WARUNKACH KRYZYSU

Źródła inicjatyw klastrowych odnaleźć można w teorii klastrów. Pojęcie klaster (ang. cluster - grono), wprowadzone przez M.E. Portera w książce pt. The competitive advantage of nations (1990), określa „geograficzne skupisko wzajemnie powiązanych firm, wyspecjalizowanych dostawców, jednostek świadczących usługi, firm działających w pokrewnych sektorach oraz związanych z nimi instytucji (np. uniwersytetów, jednostek normalizacyjnych i stowarzyszeń branżowych) w poszczególnych dziedzinach, konkurujących ze sobą, ale również współpracujących" (Porter, 2001: 246). Choć często w publikacjach naukowych pojęcie klastrów i inicjatyw klastrowych stosuje się zamiennie, w niniejszym artykule przez inicjatywy klastrowe rozumie się zinstytucjonalizowane (sformalizowane) formy współpracy przedsiębiorstw, a zatem te ich geograficzne skupienia, w których zawarto formalne, pisemne porozumienie o kooperacji. Za R. Kalupą (2007: 16) inicjatywę klastrową można również zdefiniować jako ,zorganizowany wysiłek dla zwiększenia wzrostu i konkurencyjności klastra w regionie, angażujący firmy, władze i/lub środowiska badawczo-rozwojowe".

Na podstawie przeglądu polskiej literatury przedmiotu wyróżnić można kilka charakterystycznych cech przemysłowych inicjatyw klastrowych (por. np. Gorynia, Jankowska, 2008; Mikołajczak i in., 2009; Skawińska, Zalewski, 2009; Brodzicki i in., 2012; Dyba, Kawińska, 2012; Jankowska, 2012; Kowalski, 2013). Są to:

1. Bliskość geograficzna (koncentracja przestrzenna) konkurencyjnych podmiotów wchodzących w skład klastra.

2. Specjalizacja przedsiębiorstw w ramach jednego sektora lub jednej branży.

3. Silne i trwałe powiązania między podmiotami - interakcje powinny być nastawione na wspólny cel i prowadzić do uzyskania efektu synergii (osiągnięcia wspólnie większej wartości dodatkowej, niemożliwej do uzyskania w przypadku działalności w pojedynkę).

4. Sieciowy charakter powiązań - relacje współpracy przedsiębiorstw, instytucji lokalnych i organizacji mają charakter formalny i nieformalny, są to przy tym głównie zależności poziome.

5. Koopetycja ${ }^{3}$ - powiązania mają charakter konkurencji i współpracy (współdziałania), czyli zachodzi w nich jednoczesna walka o zysk, rozwój działalności, nowych klientów

\footnotetext{
${ }^{3}$ Termin ten wywodzi się z połączenia angielskich słów: co-operation i competition.
} 
oraz kooperacja polegająca na wspólnym ulepszaniu lub wymianie wiedzy (informacji) o organizacji i technologii produkcji, wspólnej realizacji zamówień, wytwarzaniu komponentów wzajemnie dla siebie, pozyskiwaniu środków finansowych na rozwój i promocję.

Wśród korzyści dla firm funkcjonujących w ramach klastra wymienić można (Brodzicki, Szultka, 2004; Dutkowski, 2005; Karlsson, 2008; Grycuk, 2010):

- szansę na szybszy rozwój i osiągnięcie lepszych wyników,

- możliwość obniżania kosztów, m.in. poprzez nawiązywanie preferencyjnych umów z dostawcami, wykorzystywanie tych samych zasobów, wspólne zakupy, koordynowanie działań marketingowych,

- potencjalny wzrost produktywności i innowacyjności poprzez uczenie się od innych, a także ewentualną współpracę z lokalnymi uczelniami i ośrodkami badawczymi, poprzez którą możliwe jest generowanie różnorodnych nowych rozwiązań w zakresie technologii i organizacji produkcji; konkurencja w klastrze wymusza ponadto utrzymywanie najwyższej jakości i standardów, a to z kolei ułatwia ekspansję na rynkach zagranicznych (wielkość eksportu uznawana jest za jedną z najważniejszych miar oceny sukcesu ekonomicznego inicjatyw klastrowych),

- dostęp do informacji i wiedzy - poprzez sieci kontaktów firmy wymieniają się informacjami o nowych rynkach zbytu, trendach w sektorze, zmianach w oczekiwaniach klientów, nowoczesnych technologiach, materiałach i usługach; razem biorą również udział w szkoleniach, konferencjach i spotkaniach branżowych.

Krajowe i regionalne władze publiczne szybko odkryły różnorodne korzyści, w tym związane ze wzrostem regionalnej konkurencyjności, które mogą płynąć z rozwoju przedsiębiorstw w sektorach uznawanych za nawiązujące do regionalnych tradycji i specjalizacji. W latach 2007-2013, pierwszym pełnym okresie polityki regionalnej Unii Europejskiej, w którym uczestniczyła Polska, zaistniała możliwość pozyskania środków finansowych na zawiązywanie współpracy klastrowej i jej rozwój z krajowych i regionalnych programów operacyjnych (Dyba, Stryjakiewicz, 2012).

$\mathrm{Na}$ poziomie krajowym pierwszorzędną rolę w tym zakresie odgrywa działanie 5.1 Programu Operacyjnego Innowacyjna Gospodarka, zarządzanego przez Polską Agencję Rozwoju Przedsiębiorczości. Pozyskane w nim środki mogą być przeznaczone na wspólne przedsięwzięcia grup przedsiębiorców dotyczące projektów doradczych, szkoleniowych i inwestycyjnych w zakresie: tworzenia oraz zarządzania strukturą organizacyjną powiązania kooperacyjnego, przygotowania wspólnych planów rozwoju powiązań kooperacyjnych, wspólnych inwestycji grup kooperujących przedsiębiorców i rozwoju działań marketingowych. Drugim możliwym źródłem uzyskania dofinansowania na rozwój sieci powiązań między przedsiębiorstwami jest Program Operacyjny Kapitał Ludzki (wspierający głównie czynniki miękkie), a trzecim - regionalne programy operacyjne, zarządzane przez samorządy województw. Na lata 2014-2020 przewiduje się podobne możliwości finansowania współpracy przedsiębiorstw, w szczególności inicjatyw klastrowych, bądź w ramach regionalnych programów operacyjnych (które zostaną przygotowane dla 16 województw), bądź w ramach programów krajowych: PO Inteligentny Rozwój (przewidywana alokacja 8,6 mld euro) oraz PO Wiedza, Edukacja, Rozwój (4,4 mld euro; por. www.mrr.gov.pl, 2013). 
W odniesieniu do przemysłu meblarskiego inicjatywy klastrowe stanowią szczególnie dużą szansę na rozwój niewielkich zakładów stolarskich i producentów mebli, których największą siłą jest kapitał społeczny: połączenie tradycyjnych metod produkcji, nieformalnych więzi łączących producentów oraz chęci wspólnego działania na rzecz lokalnego rozwoju. Wspólny marketing i promocja oraz współpraca w produkcji i dystrybucji są również dobrą strategią dla przedsiębiorstw w czasach kryzysu gospodarczego. Obok tradycyjnych kooperantów grup producentów mebli: przedsiębiorstw dostarczających im maszyny i urządzenia, drewno i płyty, design, farby i kleje oraz firm oferujących logistykę i zarządzanie jakością, w skład inicjatyw klastrowych mogą wchodzić różnorodne instytucje otoczenia biznesu, ośrodki badań, szkoły wyższe oraz władze publiczne (ryc. 2).

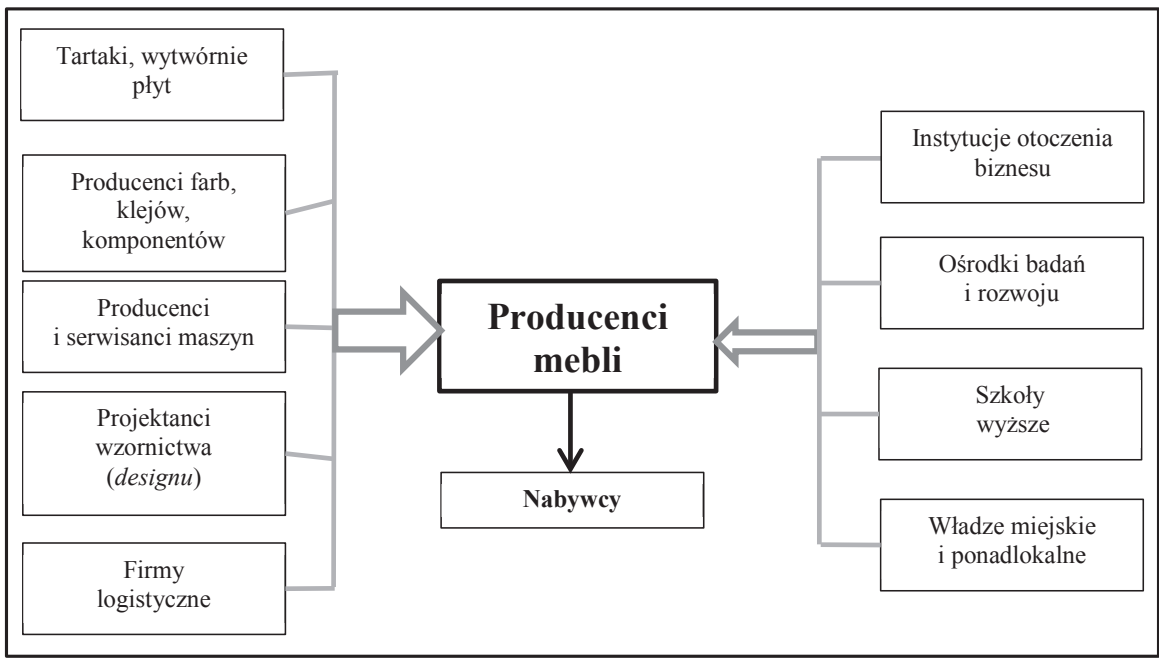

Ryc. 2. Podmioty zaangażowane w meblarską inicjatywę klastrową

Źródło: Kalupa, 2007: 16, ze zmianami

Trudno określić dokładną liczbę inicjatyw klastrowych branży meblarskiej w Polsce. Niekiedy są one tworzone odgórnie, przy dużym zaangażowaniu władz publicznych lub instytucji, w celu realizacji konkretnego projektu (podejście top-down). M.E. Porter podkreślał w swych pracach, iż nie ma żadnej gwarancji, że współpraca w klastrze się rozwinie oraz że utrzyma on zdolność do konkurowania na rynku (por. Porter, 2001). W tab. 1, na podstawie danych Polskiej Agencji Rozwoju Przedsiębiorczości, zostały przedstawione wybrane inicjatywy klastrowe branży meblarskiej w Polsce w 2013 roku. 
Tab. 1. Wybrane meblarskie inicjatywy klastrowe w Polsce w $2013 \mathrm{r}$.

\begin{tabular}{|c|c|c|c|c|}
\hline Lp. & Nazwa & Koordynator & Strona internetowa & Województwo \\
\hline 1 & Klaster Mebel Design & $\begin{array}{l}\text { Wielkopolska Izba } \\
\text { Przemysłowo- } \\
\text {-Handlowa }\end{array}$ & $\begin{array}{l}\text { www.wiph.pl/content/ } \\
\text { view/489/ }\end{array}$ & wielkopolskie \\
\hline 2 & $\begin{array}{l}\text { Klaster Przemysłu } \\
\text { Meblarskiego Polski } \\
\text { Wschodniej }\end{array}$ & $\begin{array}{l}\text { Fundacja na rzecz } \\
\text { Klastra Przemysłu } \\
\text { Meblarskiego Polski } \\
\text { Wschodniej }\end{array}$ & brak strony www & lubelskie \\
\hline 3 & $\begin{array}{l}\text { Lubawski Klaster } \\
\text { Meblowy }\end{array}$ & $\begin{array}{l}\text { Cech Rzemieślników } \\
\text { i Przedsiębiorców } \\
\text { w Lubawie }\end{array}$ & www.cech.lubawa.pl & $\begin{array}{l}\text { warmińsko- } \\
\text {-mazurskie }\end{array}$ \\
\hline 4 & $\begin{array}{l}\text { Północno-Wschodni } \\
\text { Innowacyjny Klaster } \\
\text { Drzewny }\end{array}$ & $\begin{array}{l}\text { Park Naukowo- } \\
\text {-Technologiczny } \\
\text { Polska-Wschód } \\
\text { w Suwałkach }\end{array}$ & $\begin{array}{l}\text { www.park.suwalki.pl lub } \\
\text { www.crystal.suwalki.pl }\end{array}$ & podkarpackie \\
\hline 5 & $\begin{array}{l}\text { Stowarzyszenie } \\
\text { Klaster Mebel - } \\
\text { Elbląg }\end{array}$ & $\begin{array}{l}\text { Elbląska Izba } \\
\text { Przemysłowo- } \\
\text {-Handlowa }\end{array}$ & www.klastermebel.pl & $\begin{array}{l}\text { warmińsko- } \\
\text {-mazurskie }\end{array}$ \\
\hline 6 & $\begin{array}{l}\text { Stowarzyszenie } \\
\text { Lubelskie Drewno }\end{array}$ & osoba fizyczna & www.lubelskiedrewno.pl & lubelskie \\
\hline 7 & \begin{tabular}{|l} 
Stowarzyszenie \\
Zachodniopomorskie \\
Drewno i Meble
\end{tabular} & \begin{tabular}{|l|} 
Koszaliński \\
Park Naukowo- \\
-Technologiczny \\
\end{tabular} & www.drewno.rsi.org.pl & $\begin{array}{l}\text { zachodnio- } \\
\text { pomorskie }\end{array}$ \\
\hline 8 & $\begin{array}{l}\text { Swarzędzki Klaster } \\
\text { Producentów Mebli }\end{array}$ & \begin{tabular}{|l|} 
Cech Stolarzy \\
Swarzędzkich
\end{tabular} & $\begin{array}{l}\text { www.swarzedzki-klaster. } \\
\text { com.pl }\end{array}$ & wielkopolskie \\
\hline 9 & $\begin{array}{l}\text { Śląski Klaster } \\
\text { Drzewny }\end{array}$ & \begin{tabular}{|l|} 
Izba Gospodarcza \\
Śląsk z Opola
\end{tabular} & $\begin{array}{l}\text { www.igsilesia.pl/slaski- } \\
\text { klaster-drzewny.html }\end{array}$ & śląskie \\
\hline
\end{tabular}

Źródło: opracowanie własne na podstawie: www.klastry.pi.gov.pl/PARP/data/klastry, 2013

Pogłębiona analiza kształtowania się jednej z wymienionych w tabeli inicjatyw klastrowych - Swarzędzkiego Klastra Producentów Mebli, zostanie przedstawiona w kolejnej części artykułu. Inicjatywa ta jest próbą przezwyciężenia kryzysu w branży, spowodowanego z jednej strony transformacją systemu gospodarczego w Polsce, z drugiej strony procesami globalnymi, w szczególności światowym kryzysem ekonomicznym.

\section{TradycJe MEBlarskie SWARZĘDZA JAKO PODSTAWA KSZTAŁTOWANIA SIĘ INICJATYWY KLASTROWEJ W WARUNKACH KRYZYSU}

Swarzędz przez wiele lat słynął w Polsce z produkcji mebli, wyrobów stolarskich, tapicerskich oraz drewnianych. Tradycje miasta w tej branży sięgają końca XVIII w., gdy pojawiły się pierwsze manufaktury meblarskie. Największy rozkwit swarzędzkiego meblarstwa 
nastąpił w XIX w., kiedy w wyniku zmiany koniunktury gospodarczej zaczęły upadać przeważające dotąd w mieście warsztaty tkackie i sukiennicze. Na rozwój swarzędzkiego meblarstwa szczególny wpływ miało wprowadzenie w tamtym czasie mechanicznej obróbki drewna oraz działalność władz pruskich, które sprowadziły do miasta osadników z Niemiec, biegłych w rzemiosłach związanych z obróbką drewna. Przed wybuchem I wojny światowej W warsztatach branży stolarskiej oraz siedmiu tartakach pracowało ok. 500 osób (Nawrocki, 1988). Na początku XX w. lokalny przedsiębiorca Antoni Tabaka założył Specjalną Fabrykę Krzeseł i Stołów, która kilkanaście lat później rozsławiła Swarzędz na całą II Rzeczpospolitą.

W okresie międzywojennym, gdy dynamicznie rosła liczba mieszkańców Swarzędza, ponad 3/4 siły roboczej miasta było zatrudnione w zakładach stolarskich i meblarskich. W 1929 roku Fabryka Krzeseł i Stołów A. Tabaki była najnowocześniejszą fabryką mebli w kraju, zatrudniała 270 osób i połowę produktów eksportowała do Niemiec, Holandii, Danii i Turcji (Historia swarzędzkiego fabrykanta, 2009). Rzemiosło meblarskie zrzeszone w Cechu Swarzędzkim przetrwało nawet czasy wielkiego kryzysu gospodarczego z lat 1929-1935. W 1934 roku, z inicjatywy pierwszego burmistrza Swarzędza Tadeusza Staniewskiego, w nowo wybudowanym pawilonie wystawienniczym zorganizowano po raz pierwszy Swarzędzkie Targi Meblowe (Sobczak, 2008).

Po II wojnie światowej budowa meblarskiej marki Swarzędza nabrała innego kształtu. W 1952 roku władze Polski Ludowej w oparciu o miejscowe tradycje powołały do życia państwowe przedsiębiorstwo pod nazwą Swarzędzkie Fabryki Mebli. Socjalistyczny koncern powstał przez upaństwowienie prywatnego przedsiębiorstwa Antoniego Tabaki oraz Tartaku Parowego Franciszka Zawidzkiego (sam Tabaka zmarł podczas wojny w niemieckim obozie koncentracyjnym). Z czasem przedsiębiorstwo powiększało się o kolejne zakłady produkcyjne - w 1970 roku w jego skład wchodziło 6 zakładów: dwa w Swarzędzu, po jednym w Kostrzynie, Poznaniu, Mosinie i Kościanie. W 1976 roku utworzono oddział w Rawiczu, a w 1980 roku w Gostyniu. W latach 80. XX wieku tylko w zakładach w Swarzędzu zatrudnionych było 3500 osób, a przedsiębiorstwo włączało się w lokalne inicjatywy społeczne, m.in. rozbudowując dla pracowników infrastrukturę społeczną w mieście. Swarzędzkie Fabryki Mebli rozsławiły wtedy Swarzędz w całej Polsce, zwykło się nawet mówić, że „Swarzędz drewnem stoi” i ,dobre meble to tylko ze Swarzędza” (Małyszka, 2008).

Po przemianach systemowych z 1989 roku i przejściu od gospodarki centralnie planowanej do rynkowej, Swarzędzkie Fabryki Mebli zostały w październiku 1990 roku skomercjalizowane, a następnie sprywatyzowane przez przekształcenie w spółkę akcyjną. W 1991 roku Swarzędzkie Fabryki Mebli SA były jedną z pierwszych spółek notowanych na warszawskiej Giełdzie Papierów Wartościowych (Karolczak, 2012). Przedsiębiorstwo, które w 2000 roku zmieniło nazwę na Swarzędz Meble SA, musiało w nowych warunkach gospodarczych konkurować z innymi fabrykami, w tym z zagranicy. Początki były obiecujące - jeszcze w 1995 roku swarzędzkie meble były sprzedawane w ok. 80 salonach sprzedaży o łącznej powierzchni 7000 ha, rozmieszczonych na terenie całej Polski, a także w Rydze, Lwowie, Ostrawie i Żylinie. Jednocześnie tradycyjna wysoka pozycja przedsiębiorstwa i wieloletni brak konkurencji spowodowały osłabienie adaptabilności firmy do odmiennych warunków gospodarowania, co przejawiało się w ograniczonej zdolności rozpoznawania 
nowych wyzwań i szybkiej, skutecznej reakcji na zagrożenia związane z procesami transformacji i globalizacji (Stryjakiewicz, 1999; Stryjakiewicz, 2005).

Kolejne reorganizacje systemu zarządzania (m.in. sześciu prezesów od 1990 roku), produkcji i sprzedaży prowadziły do redukcji liczby pracowników i zamykania kolejnych salonów sprzedaży. Mimo że jeszcze w 2005 roku z badań Ogólnopolskiej Izby Gospodarczej Producentów Mebli wynikało, że fabryka w Swarzędzu jest najbardziej rozpoznawalną marką mebli w Polsce, w 2009 roku zarząd spółki podjął decyzję o rozpoczęciu procesu likwidacji, wystawiając jednocześnie znak towarowy „Swarzędz” na sprzedaż (początkowo za 4,9 mln zł). Chętnych na jego zakup nie udało się dotychczas znaleźć, gdyż - jak uważają analitycy - błędy kolejnych zarządów doprowadziły do obniżenia prestiżu marki i jej wartości. Uważa się wręcz, że głównymi przyczynami stopniowego upadku przedsiębiorstwa były zła strategia marketingowa marki, słaba orientacja na rynku oraz nastawienie na nierozwojowe i niezyskowne grupy odbiorców produktów (np. na osoby starsze, zamiast na pierwsze wyposażenie mieszkań dla młodych rodzin). Dodatkowo całą branżę dotknął kryzys gospodarczy wywołany ogólnoświatowym kryzysem finansowym (Swarzędz ogłasza..., 2010; Swarzędz wyprzedaje..., 2010).

Likwidacja Swarzędzkich Fabryk Mebli nie oznaczała jednak końca stolarskich tradycji Swarzędza. Obok małych i średnich przedsiębiorstw istniejących w Swarzędzu od dziesiątek lat, utworzonych zostało kilka nowych zakładów stolarskich i meblarskich, wykorzystujących doświadczenie oraz umiejętności i kwalifikacje miejscowych pracowników. Małe i średnie przedsiębiorstwa meblarskie Swarzędza musiały przejść własny proces adaptacji do nowych warunków gospodarowania, a zwłaszcza rosnącej konkurencji krajowej i zagranicznej. Część rzemieślników zaczęła dywersyfikować swoją produkcję i elastycznie dostosowywać się do szybko zmieniających się preferencji klientów. Obok tradycyjnych drewnianych stołów i krzeseł, zaczęli produkcję mebli tapicerowanych, wyposażenia biur, hoteli i pensjonatów. Liczba czynnych zakładów rzemieślniczych zaczęła jednak szybko spadać z 450 w 1990 roku do ok. 200 pod koniec XX wieku, czemu sprzyjało złe zarządzanie reprezentacją swarzędzkiego rzemiosła - Cechem Stolarzy Swarzędzkich (Stryjakiewicz, 1999; 2004).

Zgodnie z danymi Centralnej Ewidencji i Informacji o Działalności Gospodarczej (CEIDG, stan na 9 stycznia 2014 roku) w Swarzędzu znajduje się razem 297 podmiotów branży meblarskiej. Jest to odpowiednio: 67 podmiotów w sekcji 31.01.Z - produkcja mebli biurowych i sklepowych; 29 w sekcji 31.02.Z - produkcja mebli kuchennych; 6 w sekcji 31.03.Z - produkcja materaców; $165 \mathrm{w}$ sekcji 31.09.Z - produkcja pozostałych mebli; a także $9 \mathrm{w}$ sekcji $46.47 . Z$ - sprzedaż hurtowa mebli; 4 w sekcji 46.65.Z - sprzedaż hurtowa mebli biurowych, 17 w sekcji $47.59 . Z$ - sprzedaż detaliczna mebli.

Nieco inne informacje przedstawiają dane statystyczne uzyskane w Urzędzie Miasta i Gminy Swarzędz, zgodnie z którymi w gminie na przełomie 2013 i 2014 roku zarejestrowanych było 135 zakładów szeroko rozumianej branży meblarskiej, z czego: 53 to zakłady stolarskie, 63 - tapicerskie, 14 - stolarsko-tapicerskie, 1 z zakresu renowacji mebli i 4 z zakresu usług stolarskich. Są to liczby niemałe.

Wielu spośród przedsiębiorców przynależy do lokalnego samorządu gospodarczego Cechu Stolarzy Swarzędzkich. Według danych uzyskanych w Cechu w grudniu 2013 roku, 
zrzeszonych jest w nim obecnie 77 członków, z czego 5 spoza Swarzędza. Na uwagę zasługuje fakt, że wśród członków jest aż 17 podwójnych nazwisk lub adresów, co świadczy o tym, że są to członkowie rodzin prowadzący przedsiębiorstwa wspólnie, z know-how przekazywanym z pokolenia na pokolenie. Jest to wciąż znaczny kapitał społeczny, endogeniczny czynnik, który - podobnie jak w modelu „Trzecich Włoch” - może być istotny dla pobudzania rozwoju gospodarczego (por. Stryjakiewicz i in., 2010). Ten właśnie czynnik, wzmocniony wsparciem instytucji zewnętrznych, stał się podstawą inicjatywy klastrowej.

\section{Swarzędzki Klaster Producentów Mebli - nowa Perspektywa rozwojowa}

W listopadzie 2011 roku, z inicjatywy Cechu Stolarzy Swarzędzkich oraz Wielkopolskiej Izby Rzemieślniczej (jako jednostki otoczenia biznesu), podpisany został list intencyjny o powołaniu Swarzędzkiego Klastra Producentów Mebli. Obok wyżej wymienionych instytucji, „widząc konieczność zacieśnienia współpracy w dziedzinie rozwoju innowacji oraz wdrażania nowoczesnych rozwiązań w meblarstwie", podpisało się pod nim 10 przedsiębiorstw meblarskich ze Swarzędza, a także Katedra Meblarstwa z Wydziału Technologii Drewna Uniwersytetu Przyrodniczego w Poznaniu, jako współpracująca jednostka naukowa. W liście zapisano, że misją Klastra jest rozwój marki miejsca Swarzędz jako ośrodka tradycji meblarstwa wysokiej jakości oraz wzrost długotrwałej pozycji konkurencyjnej zrzeszonych przedsiębiorstw. Celem ogólnym Klastra jest „wzajemne wspieranie się przedsiębiorców, jednostek sfery badawczo-rozwojowej i instytucji otoczenia biznesu działających w szeroko pojętej produkcji meblarskiej i wyposażenia wnętrz poprzez stałą współpracę opartą o transfer wiedzy, wdrażanie innowacyjnych rozwiązań oraz poprawę konkurencyjności podmiotów tworzących Klaster, a także wykreowanie marki miejsca Swarzędz" (List intencyjny..., 2011).

Celami szczegółowymi działalności Klastra są:

- poprawa efektywności i profesjonalizacja rozwijającej się współpracy między przedsiębiorstwami oraz zachęcanie nowych podmiotów do współpracy,

- ułatwianie wymiany technologicznej, tworzenie impulsów do uczestnictwa w projektach wymagających potencjału naukowego i regularna współpraca z podmiotami sfery badawczo-rozwojowej w celu wspierania innowacyjności,

- rozwijanie potencjału produkcyjnego, projektowego i usługowego kooperujących przedsiębiorstw,

- współpraca z jednostkami administracji publicznej: rządowej i samorządowej,

- stworzenie wspólnej reprezentacji przedsiębiorców Klastra i współdziałanie wobec partnerów handlowych po stronie klientów oraz dostawców,

- współpraca w zakresie marketingu i działań handlowych, szczególnie na rynkach europejskich,

- odbudowa marki miejsca Swarzędz i stworzenie jednolitego wizerunku, nawiązującego do wielowiekowych tradycji rzemieślniczych miasta. 
Do powyższych celów w liście intencyjnym przypisane zostały zadania, z wyszczególnieniem zadań dla przedsiębiorców, jednostek naukowych, jednostek wspierających oraz koordynatora Klastra, powołanego do pełnienia funkcji reprezentacyjnych i administracyjnych w imieniu Cechu Stolarzy Swarzędzkich. Jak zaznaczono w dokumencie, Klaster ma charakter otwarty, co oznacza, że mogą do niego przystąpić kolejni członkowie.

W 2012 roku Cech Stolarzy Swarzędzkich pozyskał dofinansowanie z Programu Operacyjnego Innowacyjna Gospodarka (PO IG) na projekt pt. Budowa strategii rozwoju Swarzędzkiego Klastra Producentów Mebli. Jest to pierwszy z zakładanych projektów, z dofinansowaniem w wysokości 70\% kosztów kwalifikowanych, realizowany w ramach działania 5.1 PO IG - wsparcia powiązań kooperacyjnych o znaczeniu ponadregionalnym. Projekt zakłada: (1) wyposażenie i umeblowanie salki szkoleniowej oraz pracowni projektowej w siedzibie Cechu, (2) zakup wartości niematerialnych i prawnych: logo, strony internetowej, programów do projektowania mebli i obróbki zdjęć, (3) doradztwo - zakup usług eksperckich i badawczych, a także (4) szkolenia dla członków porozumienia: z obsługi programu do projektowania mebli, zarządzania projektem, prowadzenia rozmów handlowych, obsługi klienta, merchandisingu.

Projekt znajduje się w fazie realizacji, ale już zauważa się wzrost zainteresowania inicjatywą, także ze strony lokalnych władz. W 2014 roku, przy współudziale środków gminy, odnowiono salon sprzedaży - zabytkowy budynek Cechu Stolarzy Swarzędzkich. Dalsza integracja środowiska i realizacja nowych inicjatyw może przynieść kolejne efekty mnożnikowe $\mathrm{w}$ mieście i regionie oraz przyspieszyć wychodzenie z kryzysu swarzędzkiego meblarstwa.

Obecnie trudno przewidzieć przyszłość inicjatywy Swarzędzkiego Klastra Producentów Mebli. Wcześniej, w 2009 roku, został podpisany list intencyjny w sprawie utworzenia innej inicjatywy - Klastra Meblarzy Swarzędzkich. Inicjatorem porozumienia była wówczas Wielkopolska Izba Przemysłowo-Handlowa, a sygnatariuszami - miasto i gmina Swarzędz, powiat poznański, Katedra Meblarstwa Wydziału Technologii Drewna Uniwersytetu Przyrodniczego w Poznaniu, Instytut Inżynierii Zarządzania Politechniki Poznańskiej oraz ponad 30 swarzędzkich zakładów meblarskich i stolarskich (w tym dwa średniej wielkości, dynamiczne przedsiębiorstwa). Zakładane cele były wówczas jeszcze ambitniejsze niż w wypadku Swarzędzkiego Klastra Producentów Mebli (m.in. stworzenie warunków do kształcenia nowoczesnych kadr wraz z popularyzacją zawodu meblarza, por. Meble ze Swarzędza..., 2009; Stryjakiewicz i in., 2010). Niestety, zabrakło wyraźnego lidera, który potrafiłby zintegrować producentów. Nie udało się również pozyskać zewnętrznych środków finansowych na wspólną działalność, stąd inicjatywa ta znalazła się w zawieszeniu. Obecnie rozważa się połączenie dwóch swarzędzkich inicjatyw w jedno, silne porozumienie producentów mebli i jednostek otoczenia biznesu. Z pewnością renomowane i eleganckie meble swarzędzkie powinny być produkowane z uwzględnieniem zmieniających się dynamicznie oczekiwań klientów, co zapewni dalszy rozwój firm swarzędzkiego klastra. 


\section{ZAKOŃCZENIE}

Odpowiedź na pytanie, czy i w jakim stopniu przemysł meblarski stanie się trwałą specjalizacją polskiej gospodarki, skutecznie adaptującą się do zmieniających się warunków zewnętrznych, pozostaje ciągle otwarta. Dotychczasowe doświadczenia dowodzą, że odporność branży na kryzys okazała się dość duża, a liczba inicjatyw klastrowych świadczy o istniejącym potencjale rozwojowym. Przykład Swarzędza pokazuje, że warto podejmować inicjatywy integracji przedsiębiorstw, które opierają się na kapitale społecznym i wieloletnich tradycjach, gdyż mają one duże szanse na sukces na rynku krajowym i międzynarodowym.

\section{Literatura \\ References}

Brodzicki, T., Ciołek, D., Tarkowski, M. (2012). Mapowanie klastrów w Polsce - próba dostosowania metody. W: T. Brodzicki, J. Kuczewska (red.). Klastry i polityka klastrowa w Polsce. Konkurencyjność przedsiębiorstw, sektorów i regionów. Gdańsk: Wydawnictwo Naukowe UG, 60-98.

Brodzicki, T., Szultka, R. (red.). (2004). Klastry - innowacyjne wyzwanie dla Polski. Gdańsk: Instytut Badań nad Gospodarką Rynkową.

Centralna Ewidencja i Informacja o Działalności Gospodarczej (2013, 27 listopada). Pozyskano z https://prod.ceidg.gov.pl/ceidg.cms.engine/

Dutkowski, M. (2005). Klastry w rozwoju regionalnym. W: T. Czyż, H. Rogacki(red.). Współczesne problemy i koncepcje teoretyczne badań przestrzenno-ekonomicznych. Warszawa: Biuletyn Komitetu Przestrzennego Zagospodarowania Kraju Polskiej Akademii Nauk, 219, 57-73.

Dyba, W.M., Kawińska, M. (2012). Klasyfikacja rodzajowa i polityka wspierania klastrów gospodarczych w województwie wielkopolskim. Biuletyn Instytutu Geografii Społeczno-Ekonomicznej i Gospodarki Przestrzennej Uniwersytetu im. Adama Mickiewicza w Poznaniu. Seria Rozwój Regionalny i Polityka Regionalna, nr 20. Poznań: Wydawnictwo Naukowe Bogucki, 73-85.

Dyba, W.M., Stryjakiewicz, T. (2012). Zróżnicowanie poziomu rozwoju społeczno-gospodarczego gmin województwa wielkopolskiego $w$ świetle realizacji polityki intraregionalnej. Poznań: Wydawnictwo Naukowe Bogucki.

Fundusze Europejskie 2014-2020 - informacje ogólne. (2013, 5 grudnia). Pozyskano z http://www. mir.gov.pl/fundusze/fundusze_europejskie_2014_2020/strony/start.aspx

Gorynia, M., Jankowska, B. (2008). Klastry a międzynarodowa konkurencyjność i internacjonalizacja przedsiębiorstwa. Warszawa: Wydawnictwo Diffin.

Grycuk, A. (2010). Klastry jako instrument polityki regionalnej. Infos - zagadnienia społeczno-gospodarcze. Biuro Analiz Sejmowych nr 13 (83).

Historia swarzędzkiego fabrykanta (2009, 8 marca). Gazeta Wyborcza. Poznań.

IKEA Group Sustainability Report 2012 (2013, 5 grudnia). Pozyskano z http://franchisor.ikea.com/ FranchisingtheIKEAway/Pages/All-IKEA-stores.aspx

Interaktywna mapa klastrów i inicjatyw klastrowych w Polsce (2013, 27 listopada). Pozyskano z http:// www.klastry.pi.gov.pl/PARP/data/klastry

Jankowska, B. (2012). Koopetycja w klastrach kreatywnych. Przyczynek do teorii regulacji w gospodarce rynkowej. Poznań: Wydawnictwo UEP.

Kalupa, R. (2007). Strategia rozwoju Wielkopolskiego Klastra Meblarskiego. Poznań: Wielkopolska Agencja Rozwoju Przedsiębiorczości.

Karlsson, C. (red.) (2008). Handbook of research on innovations and clusters: cases and policies. Edwar Elgar, Cheltenham, Northampton. 
Karolczak, M. (2012). Swarzędzkie Fabryki Mebli - 60 lat minęto... Pozyskano z http://www.sm-swarzedz.pl/go.php/pl/nasze_miasto_nasze_sprawy/2012/swarzedzkie_fabryki_mebli_60.html

Koszarek, M. (2005). Przemysł meblarski. W: M. Szultka, M. Koszarek, D. Piwowarczyk. Wstepna analiza trzech potencjalnych klastrów w województwie zachodniopomorskim. Instytut Badań nad Gospodarką Rynkową, 27-43.

Kowalski, M.A. (2013). Znaczenie klastrów dla innowacyjności gospodarki w Polsce. Warszawa: Oficyna Wydawnicza SGH.

List intencyjny o powołaniu Swarzędzkiego Klastra Producentów Mebli (listopad 2011, niepublikowany).

Lista 500 Polityki. Ranking największych przedsiębiorstw w Polsce pod względem przychodów ze sprzedaży (2013, 20 listopada). Pozyskano z http://www.lista500.polityka.pl/rankings/show/industry: 188

Małyszka, A. (2008). Swarzędz 1638-2008. W: Swarzędz na starych pocztówkach. Ze zbiorów i w opracowaniu Piotra Choryńskiego. Swarzędz: Wydanie specjalne swarzędzkiego miesięcznika regionalnego „Prosto z ratusza” z okazji 370-lecia lokacji Swarzędza.

Meble ze Swarzędza chcą razem podbić rynek. (2009, 6 sierpnia). Gazeta Wyborcza. Poznań.

Mikołajczak, B., Kurczewska, A., Fila, J. (2009). Klastry na świecie. Studia przypadków. Warszawa: Wydawnictwo Diffin.

Nawrocki, S. (1988). Dzieje Swarzędza. Swarzędz: Publikacja sfinansowana przez Społeczny Komitet Obchodów 350-lecia miasta Swarzędza.

Ogólnopolska Izba Gospodarcza Producentów Mebli - informacje ogólne (2013, 18 listopada). Pozyskano z http://www.oigpm.org.pl/index.php

Okrzesik, J. (2009). Ze Swarzędza nie zostanie nawet marka. GP Forsal. Pozyskano z http://forsal.pl/ artykuly/310130,ze_swarzedza_nie_zostanie_nawet_marka.html

Pokonać kryzys - uwarunkowania makro- i mikroekonomiczne polskiej branży meblarskiej (2013, 18 listopada). Pozyskano zhttp://www.meble.org.pl/meble_branza_a.php?id_modul=artykuly\&id=19

Porter, M.E. (1990). The competitive advantage of nations. Hampshire and London: Macmillan Press.

Porter, M.E. (1996). What is Strategy? W: Harvard Business Review, 61-78.

Porter, M.E. (2001). Porter o konkurencji. Warszawa: Polskie Wydawnictwo Ekonomiczne.

Porter, M.E. (2008). The five competitive forces that shape strategy. W: Harvard Business Review (Reprint), 24-40.

Skawińska, E., Zalewski, R.I. (2009). Klastry biznesowe w rozwoju konkurencyjności i innowacyjności regionów. Świat-Europa-Polska. Warszawa: PWE.

Sobczak, J. (2008). Swarzędz. W: H. Błachnio (red.). Swarzędz i okolice. Swarzędz: Wydawnictwo Debiuty.

Stryjakiewicz, T. (1999). Dialektyka „globalność-lokalność”. Konflikty między strategiami globalnymi i lokalnymi (na przykładzie przemysłu meblarskiego). W: Adaptacja przestrzenna przemystu w Polsce w warunkach transformacji, Poznań: Wydawnictwo Naukowe UAM, 153-158.

Stryjakiewicz, T. (2004). Sieci gospodarcze w Polsce w warunkach transformacji systemowej. W: J.J. Parysek (red.). Rozwój regionalny i lokalny w Polsce w latach 1989-2002. Poznań: Bogucki Wydawnictwo Naukowe, 25-44.

Stryjakiewicz, T. (2005). Contrasting Experiences with Business networking in a Transition Economy: The Case of Poland. W: Alvstam C.G., Schamp E.W. Linking Industries Across The World: Processes of Global Networking. Aldershot, Burlington: Ashgate, 197-222.

Stryjakiewicz, T., Szkudlarek, K., Górny, J. (2010). Stolarstwo i przemysł meblarski. W: T. Kaczmarek (red.) Ilustrowany Atlas Aglomeracji Poznańskiej. Poznań: Bogucki Wydawnictwo Naukowe.

Strzelecki, M. (2013). Powolne wychodzenie z recesji. Meble News, 12. Warszawa: Ogólnopolska Izba Gospodarcza Producentów Mebli.

Swarzędz ogłasza: Wszystko na sprzedaż (2010, 23 luty). Gazeta Wyborcza. Poznań.

Swarzędz wyprzedaje krzesła na Allegro (2010, 2 marca). Gazeta Wyborcza. Poznań. 
Wojciech M. Dyba, mgr inż., Uniwersytet im. Adama Mickiewicza w Poznaniu. Absolwent gospodarki przestrzennej na UAM w Poznaniu (2011) oraz administracji w Wyższej Szkole Bankowej w Poznaniu (2012), doktorant w Instytucie Geografii Społeczno-Ekonomicznej i Gospodarki Przestrzennej UAM. Współautor 2 monografii naukowych, autor lub współautor 11 artykułów i rozdziałów w recenzowanych czasopismach i monografiach naukowych. W pracy badawczej zajmuje się tematyką klastrów i sieci w gospodarce regionalnej, polityką regionalną oraz strategiami rozwoju regionalnego i lokalnego. Stypendysta Fundacji UAM w Poznaniu na rok 2014/2015.

Wojciech M. Dyba, MSc., Adam Mickiewicz University in Poznan, Poland.

In 2011 he graduated from the Adam Mickiewicz University in Poznan, where he studied Spatial Management and in 2012 graduated from Administration at the Higher School of Banking in Poznan. $\mathrm{He}$ is a Ph.D. student at the Adam Mickiewicz University in Poznan in the Institute of Socio-Economic Geography and Spatial Management. He co-authored 2 academic monographs and is the author or a co-author of 11 articles or chapters in academic journals or books. In his research he deals with clusters and networks in the regional economy, regional policy and strategies for local and regional development. He holds a scholarship of the AMU Foundation for the academic year 2014/2015.

Tadeusz Stryjakiewicz, prof. dr hab., Uniwersytet im. Adama Mickiewicza w Poznaniu.

Dyrektor Instytutu Geografii Społeczno-Ekonomicznej i Gospodarki Przestrzennej Uniwersytetu im. Adama Mickiewicza w Poznaniu, kierownik Zakładu Polityki Regionalnej i Integracji Europejskiej. Stypendysta Fundacji na rzecz Nauki Polskiej i Fundacji Volkswagena. Odbył staże zagraniczne na Uniwersytecie im. Johanna Wolfganga Goethego we Frankfurcie nad Menem oraz w Szkole Studiów Slawistycznych i Wschodnioeuropejskich University College w Londynie. Wykładowca wizytujący na Uniwersytecie im. Erazma w Rotterdamie. Główne zainteresowania naukowe: geografia ekonomiczna, lokalizacja działalności gospodarczej, rozwój regionalny i lokalny, organizacja i dynamika przestrzeni społeczno-ekonomicznej (w tym rozwój sektora kreatywnego). Uczestnik kilkunastu krajowych i międzynarodowych projektów badawczych; autor lub współautor 240 publikacji naukowych oraz licznych ekspertyz i raportów. Członek Centralnej Komisji ds. Stopni i Tytułów oraz wielu rad i stowarzyszeń naukowych.

Tadeusz Stryjakiewicz, professor, Adam Mickiewicz University in Poznan, Poland.

$\mathrm{He}$ is the Head of the Institute of Socio-Economic Geography and Spatial Management of the Adam Mickiewicz University in Poznań (Poland), and Head of the Department of Regional Policy and European Integration. He was a fellow at the Johann Wolfgang Goethe University, Frankfurt am Main, and in the School of Slavonic and East European Studies, University of London. He was a visiting lecturer at the Erasmus University in Rotterdam. His main research interests include: economic geography; location of economic activity; regional and local development; organisation and dynamics of socio-economic space (including creative industries). He has participated in several national and international research projects, authored (or co-authored) 240 research publications and many expert reports. He is a member of the Central Commission for Scientific Degrees and Titles and of many research councils and institutions.

\section{Adres/address:}

Uniwersytet im. Adama Mickiewicza w Poznaniu Instytut Geografii Społeczno-Ekonomicznej i Gospodarki Przestrzennej ul. Dzięgielowa 27, 61-680 Poznań, Polska

e-mail:wojtek@amu.edu.pl

e-mail: tadek@amu.edu.pl

www: www.zprie.amu.edu.pl 